\title{
A PATH ANALYSIS ON THE BIOPSYCHOSOCIAL DETERMINANTS OF MULTI DRUG RESISTANT TUBERCULOSIS IN SURAKARTA
}

\author{
Lina Alfiyani'), Setyo Sri Rahardjo²), Bhisma Murti1) \\ ${ }^{1)}$ Masters Program in Public Health, Universitas Sebelas Maret \\ ${ }^{2)}$ Faculty of Medicine, Universitas Sebelas Maret
}

\begin{abstract}
Background: Multidrug-resistant tuberculosis (MDR-TB) causes significant problem and cost for national TB control program. MDR-TB constitutes an increasing public health concern globally. The prevalence of MDR-TB is as high as 50\%. One third of all newly detected TB patients are infected with MDR strains. This study aimed to analyze the bio-psychosocial determinants of MDRTB in Surakarta, Central Java.

Subjects and Method: This was a case control study conducted in Dr. Moewardi Hospital and BBKPM, Surakarta, from September to November 2017. A sample consisting of 76 MDR-TB patients and 228 non MDR-TB patients were selected for this study by fixed disease sampling. The dependent variable was MDR-TB. The independent variables were age, drug-taking adherence, depression, comorbidity, drug side-effect, drug-taking supervisor, and family income. The data were collected using a set of questionnaire and analyzed by path analysis.

Results: MDR-TB directly increased with the lack of drug-taking adherence $(b=$ $-1.7 ; 95 \% \mathrm{CI}=-2.23$ to $-1.07 ; \mathrm{p}=0.001)$ and comorbidity $(\mathrm{b}=1.5 ; 95 \% \mathrm{CI}=0.76$ to 2.30; $\mathrm{p}=0.001)$. MDR-TB indirectly increased with depression, drug side effect, weak drug-taking supervision, and older age.

Conclusion: MDR-TB directly increases with the lack of drug-taking adherence and comorbidity. MDR-TB indirectly increases with depression, drug side effect, weak drug-taking supervision, and older age.
\end{abstract}

Keywords: bio-psychosocial determinants, MDR-TB

\section{Correspondence:}

Lina Alfiyani. Masters Program in Public Health, Sebelas Maret University, Jl. Ir. Sutami 36 A, Surakarta, Central Java. Email: linabbt@gmail.com. 